\title{
PENGARUH DISIPLIN KERJA, KEPUASAN KERJA DAN LOYALITAS KARYAWAN TERHADAP KINERJA KARYAWAN AGROWISATA BAGUS AGRO PELAGA
}

\section{(The Effect of Work Discipline, Job Satisfaction and Employee Loyalty on The Performance of Bagus Agro Pelaga Agrotourism Employess)}

\author{
Ni Putu Novi Sri Astiti, I Ketut Suamba dan Ni Wayan Putu Artini \\ Program Studi Agribisnis Fakultas Pertanian Universitas Udayana \\ J1. PB. Sudirman Denpasar, 80232, Bali, Indonesia \\ Email : novisriastiti@gmail.com
}

Diterima 30 April 2019, disetujui 29 Mei 2019

\begin{abstract}
ABSTRAK
Kinerja karyawan ditentukan oleh disiplin kerja yang diterapkan, kepuasan kerja yang dirasakan serta, rasa loyalitas yang diberikan kepada perusahaan maka dengan sendirinya akan timbul kinerja karyawan yang baik. Penelitian ini bertujuan untuk mengetahui pengaruh disiplin kerja, kepuasan kerja dan loyalitas karyawan terhadap kinerja karyawan. Penelitian ini dilaksanakan di Agrowisata Bagus Agro Pelaga. Populasi dalam penelitian ini sebanyak 84 orang. Teknik pengambilan sampel menggunakan metode proposional random sampling dengan sampel yang ditetapkan sebanyak 46 responden. Data diperoleh menggunakan kuesioner dengan teknik penilaian skala Likert 1-5. Metode analisis menggunakan Structural Equation Modeling (SEM) melalui pendekatan Partial Least Squares (PLS) yang dibantu dengan software smartPLS V.3.0. Hasil penelitian menunjukkan bahwa disiplin kerja, kepuasan kerja dan loyalitas karyawan memiliki pengaruh yang moderate (sedang) dan signifikan terhadap kinerja karyawan. Melalui penerapan disiplin kerja, kepuasan kerja dan loyalitas karyawan pada suatu perusahaan akan mampu meningkatkan kinerja dari karyawan.
\end{abstract}

Kata Kunci: disiplin kerja, kepuasan kerja, loyalitas karyawan dan kinerja karyawan.

\begin{abstract}
Employee performance is determined by the work discipline that is applied, perceived job satisfaction, and a sense of loyalty that is given to the company so that it will naturally arise good employee performance. This study aims to determine the effect of work discipline, job satisfaction and employee loyalty on employee performance. This research was conducted at Bagus Agro Pelaga Agro Tourism. The population in this study were 84 people. The sampling technique uses the proportional random sampling method with a sample of 46 respondents. Data were obtained using a questionnaire with 1-5 Likert scale assessment techniques. The method of analysis uses Structural Equation Modeling (SEM) through the Partial Least Squares (PLS) approach which is assisted by software smart PLS V.3.0. The results showed that work discipline, job satisfaction, and employee loyalty had a moderate (significant) and significant influence on employee performance. through the application of work discipline, job satisfaction and employee loyalty to a company will be able to improve the performance of employees.
\end{abstract}

Keywords: discipline, job satisfaction, employee loyalty, employee performance. 


\section{PENDAHULUAN}

Sumber daya manusia merupakan tokoh utama didalam suatu organisasi maupun perusahaan. Pada era golablisasi saat ini persaingan dalam dunia usaha semakin ketat bukan hanyalah manusia yang merupakan hal terpenting bagi suatu perusahaan, akan tetapi kinerja juga merupakan sutau hal yang harus diperhatikan secara ketat oleh setiap perusahaan. Perusahaan yang memiliki kinerja yang baik merupakan suatu perusahaan yang berhasil dalam pangsa pasar yang dibidiknya. Organisasi yang baik adalah organisasi yang berusaha meningkatkan kemampuan sumber daya manusianya, karena hal tersebut merupakan faktor utama untuk meningkatkan kinerja karyawan (Sajangbati, 2013). Pengelolaan sumber daya manusia dalam suatu perusahaan harus diperhatikan dengan baik melalui fungsi-fungsi manajemen sumber daya manusia seperti perencanaan, pengorganisasian, pengarahan, pengendalian, pengembangan, kompensasi, pengintegrasian, pemeliharaan, kedisiplinan dan pemberhentian. Fungsi manajemen sumber daya manusia tersebut akan menciptakan kedisiplinan, kepuasan kerja dan rasa loyalitas yang nantinya menghasilkan kinerja karyawan yang baik.

Penerapan disiplin kerja dalam suatu perusahaan dapat sebagai kunci keberhasilan dan meningkatkan kinerja karyawan. Disiplin merupakan sikap kesediaan dan kerelaan seseorang untuk mematuhi dan menaati norma-norma peraturan yang berlaku di sekitarnya. Menilai sikap disiplin seorang karyawan dapat menunjukkan karakteristik dari masing-masing karyawan (Sutrisno, 2009). Selain penerapan disiplin kerja untuk meningkatkan kinerja karyawan maka akan lebih baik jika diimbangi dengan rasa loyalitas yang baik dari masing-masing karyawan yang mengelola perusahaan tersebut. Loyalitas sumber daya manusia pada suatu perusahaan dapat ditimbulkan dari rasa kepuasan kerja yang telah dirasakan dan sangat erat kaitannya dengan kinerja dari masing-masing sumber daya manusia.
Agrowisata Bagus Agro Pelaga merupakan salah satu agrowisata yang sudah sangat terkenal di daerah Bali. Agrowisata ini menawarkan banyak aktivitas atau kegiatan dalam bidang pertanian dan dalam satu kawasan agrowisata ini terdapat fasilitas akomodasi seperti villa, restaurant dan meeting room yang dapat dinikmati oleh para wisatawan yang berkunjung. Sesuai data observasi yang diperoleh, Agrowisata Bagus Agro Pelaga melibatkan masyarakat sekitar atau penduduk lokal sebagai karyawan yang terlibat di dalam pengelolaan Agrowisata. Permasalahan karyawan dalam menilai kedisiplinan dan loyalitas karyawan Agrowisata Bagus Agro Pelaga kerap terjadi pada saat hari raya suci umat agama hindu dan upacara keagamaan piodalan Pura Pucak Mangu sesuai adat istiadat setempat. Hal tersebut akan lebih mendominasi karyawan untuk tidak hadir secara bersamaan dan tingkat absensi karyawan juga cukup tinggi. Terdapat beberapa karyawan yang mengundurkan diri disebabkan oleh faktor internal kurang mampu untuk mencapai target kerja yang ditentukan oleh Agrowisata Bagus Agro Pelaga. Selain itu terdapat beberapa karyawan yang merasa belum cukup puas terhadap gaji yang mereka terima selama bekerja di Agrowisata Bagus Agro Pelaga. Jika permasalahan tersebut terus menerus terjadi maka dapat mempengaruhi kinerja karyawan Agrowisata Bagus Agro Pelaga. Sehingga dari uraian permasalahan tersebut maka perlu diadakan penelitian tentang pengaruh disiplin kerja, kepuasan kerja dan loyalitas karyawan terhadap kinerja karyawan Agrowisata Bagus Agro Pelaga. Adannya penerapan disiplin kerja, kepuasan kerja dan loyalitas karyawan akan meningkatkan kinerja dari karyawan. Adapun tujuan dalam penelitian ini adalah untuk menganalisis karakteristik karyawan Agrowisata Bagus Agro Pelaga dan menganalisis seberapa besar pengaruh antar variabel disiplin kerja, kepuasan kerja dan loyalitas terhadap kinerja karyawan Agrowisata Bagus Agro Pelaga. 


\section{METODEPENELITIAN}

Penelitian ini dilaksanakan pada Agrowisata Bagus Agro Pelaga yang beralamatkan di Jalan Raya Pucak Padang Mangu, Desa Pelaga, Kecamatan Petang, Kabupaten Badung Utara. Penelitian ini berlangsung dari bulan Januari sampai dengan bulan Maret 2019. Pemilihan lokasi penelitian ditentukan dengan metode purposive berdasarkan pertimbangan tertentu. Populasi dalam penelitian ini adalah seluruh karyawan Agrowisata Bagus Agro Pelaga sejumlah 84 orang. Penetuan jumlah sampel pada penelitian ini menggunakan rumus Slovin dengan error margin 1\% sehingga jumlah responden yang ditetapkan sebanyak 46 responden. Metode pengambilan sampel yang digunakan adalah secara purposive dan proposional random sampling.

Tabel 1. Jumlah pengambilan sampel

\begin{tabular}{ccc}
\hline Metode & Divisi & $\begin{array}{c}\text { Jumlah } \\
\text { (orang) }\end{array}$ \\
\hline Proposional & HRD & 3 \\
random & Produk & 14 \\
sampling & Properti & 2 \\
& Agro & 22 \\
\hline & Manajer Resort & 1 \\
Purposive & Manajer HRD & 1 \\
sampling & Manajer Produk & 1 \\
& Manajer Properti & 1 \\
& Manajer Agro & 1 \\
\hline \multicolumn{2}{c}{ Total Sampel (Responden) } & 46 \\
\hline
\end{tabular}

Jenis data yang digunakan dalam penelitian ini dapat dikelompokkan menjadi dua yaitu kualitatif dan kuantitatif. Data kualitatif yang digunakan berupa gambaran umum Agrowisata Bagus Agro Plaga, struktur organisasi dan uraian tugas karyawan. Data kuantitatif yang digunakan adalah data yang diisi oleh karyawan Agrowisata Bagus Agro Pelaga. Sumber data yang digunakan dalam penelitian ini adalah data primer dan data skunder. Data primer yang digunakan adalah data yang diperoleh langsung dari responden dengan cara penyebaran kuesioner ke sejumlah responden yang telah ditetapkan. Data skunder yang digunakan adalah data yang diperoleh secara tidak langsung atau melalui media perantara dan dikumpulkan oleh pihak lain yang berkaitan dengan permasalahan penelitian. Data dalam penelitian ini akan dikumpulkan dengan metode observasi, metode wawancara, metode survey, metode dokumentasi, dan studi pustaka. Variabel yang digunakan dan dianalisis dalam penelitian ini diantaranya disiplin kerja dengan empat indikator, kepuasan kerja dengan lima indikator, loyalitas karyawan dengan enam indikator dan kinerja karyawan dengan delapan indikator. Masing-masing variabel adalah variabel laten atau variabel yang sulit diamati secara langsung karena peneliti mengamati masalah sosial yang menyangkut pendapat atau persepsi responden. Pengukuran dalam penelitian ini menggunakan skala likert 1-5 untuk mengukur variabel-variabel yang akan diteliti. Analisis data dalam penelitian ini menggunakan pendekatan Partial Least Square (PLS). PLS adalah model persamaan Structural Equation Modeling (SEM) yang berbasis komponen atau varian dan dapat menjawab penelitian dalam bidang sosial atau variabel yang sulit diamati secara langsung dengan melihat nilai pengaruh yang terjadi diantara kedua variabel yang diamati (Santosa, 2018). Untuk menjawab rumusan masalah penelitian, dalam PLS dapat melakukan evaluasi model dengan pengujian model pengukuran (outer model) dan model struktural (inner model) yang dibantu dengan software smartPLS V.3.0. Pengujian (outer model) untuk mengetahui hubungan antara indikator dengan variabel yang diwakilkan. Pengujian outer model terdapat tiga uji yaitu uji validitas konvergen dengan melihat nilai loading factor $>0,7$ untuk masing-masing indikator, uji validitas diskriminan dengan melihat nilai cross loading $>0.7$ dan reliabilitas dengan melihat nilai composit reliability dan chronbha alpha $>0.5$. Pengujian model struktural (inner model) untuk melihat pengaruh yang terjadi diantara 
kedua variabel yang terhubung. Pengujian model struktural (inner model) dengan melihat nilai $\mathrm{R}^{2}$ untuk masing-masing variabel terikat, uji kedua dalam inner model adalah uji GoF (Goodness of Fit) untuk melihat kebaikan dari model jalur yang dibangun dengan melihat nilai SRMR, ChiSquare dan NFI dan ketiga adalah uji Path Coefficient untuk mengetahui seberapa besar pengaruh dan hubungan yang terjadi antara variabel bebas dan variabel terikat yang diteliti dengan melihat nilai original sample, t-statistic dan P-value. Semua uji model tersebut dapat menjawab rumusan masalah yang diteliti dan mengkonfirmasi teori (Santosa, 2018). Penelitian yang dilakukan oleh Suryawardani (2018) mengenai permasalahan sosial dengan judul riset "Evaluation Of Marketing Strategy Of Sanur Village Festival Based On Visitor's Behavior" dengan menerapkan analisis SEM-PLS yang dibantu dengan software smartPLS V.3.0.

\section{HASIL DAN PEMBAHASAN}

\section{Karakteristik Responden}

Berdasarkan data yang diperoleh dari penyebaran kuesioner pada penelitian ini karakteristik responden Agrowisata Bagus Agro Pelaga didominasi oleh masyarakat setempat dengan rata-rata usia masih produktif dan berstatus sudah menikah. Sebagian besar responden Agrowisata Bagus Agro Pelaga didomonasi oleh kaum perempuan dan rata-rata memiliki tingkat pendidikan terakhir pada jenjang SMA/SLTA. Rata-rata lama kerja karyawan pada Agrowisata Bagus Agro Pelaga selama kurang lebih enam tahun. Dari hasil analisis tersebut dapat diketahui bahwa karyawan Agrowisata Bagus Agro Pelaga memiliki karakteristik yang tidak jauh berbeda dengan karyawan pada perusahaan pada umumnya, hanya saja karyawan Agrowisata Bagus Agro Pelaga lebih didominasi oleh masyarakat setempat. selain itu tingkat pendidikan yang serata SMA/SLTA harus ditingkatkan kembali ke jenjang yang lebih tinggi untuk lebih mengasah kemampuan dan keahlian terutama pada bidang pariwisata. Dari hal tersebut akan mempengaruhi rasa disiplin, rasa puas dan sikap setia dari masing-masing karyawan.

\section{Evaluasi Model Pengukuran (Outer Model)}

Model pengukuran atau Outer model merupakan evaluasi model untuk melihat hubungan antara variabel dengan indikatorindikatornya yang dapat dilihat dari nilai validitas konvergen, validitas diskriminan, dan konsistensi internal atau Cronbach's alpha, reliabilitas gabungan (Santosa, 2018). Dalam penelitian ini indikator diukur memalui indikator reflektif dan pembahasannya sebagai berikut :

\section{Validitas konvergen}

Hasil analisis menunjukkan bahwa semua nilai loading factor untuk masingmasing indikator di atas 0,7. Artinya merujuk dari teori (Santosa, 2018) semua indikator dinyatakan valid dan layak digunakan dalam penelitian karena memenuhi kriteria validitas konvergen.

Pengujian reliabilitas menunjukkan seluruh konstruk/variabel yang diukur pada penelitian ini memiliki nilai cronbach's alpha, composite reliability dan AVE rata-rata 0.9 maka nilai tersebut lebih besar dari 0.7. Hasil tersebut merujuk pada teori (Santosa, 2018) maka dapat dikatakan semua konstruk reliabel.

2. Validitas diskriminan

Hasil analisis menunjukkan bahwa untuk setiap blok indikator yang berada pada suatu konstruk yang diwakili lebih besar nilainya dibandingkan dengan blok indikator kepada konstruk lain dengan rata-rata nilai cross loading untuk masingmasing indikator sebesar 0.9. Hasil tersebut sudah memenuhi kriteria Santosa (2018) yang menyatakan untuk masingmasing indikator nilai cross loading diatas 0,7 sehingga validitas diskriminan dalam penelitian ini dinyatakan valid. 


\section{Evaluasi Model Struktural (Inner Model)}

Evaluasi model struktural merupakan pengukuran untuk menjawab rumusan masalah mengenai pengaruh disiplin kerja, kepuasan kerja, dan loyalitas karyawan terhadap kinerja karyawan. Pengujian model struktural dengan cara uji koefisien determinasi, uji GoF (Goodness of Fit) dan uji path coefficients untuk menguji hipotesis yang diajukan. Dalam penelitian ini menggunakan 4 hipotesis dan pengujiannya dapat dilakukan dengan cara Bootstraping pada software SmartPLS V.3.0. Berdasarkan kerangka model dan hipotesis yang dibangun dalam penelitian ini maka dapat ditampilkan hasil analisis model persamaan struktural yang dapat dilihat dari Gambar. 1 sebagai berikut :

1. Uji Koefisien Determinasi ( $R$ square)

Uji koefisien determinasi merupakan salah satu uji untuk melihat korelasi antar konstruk dengan melihat nilai $R$-square $>0.25$ yang artinya menunjukkan pengaruh yang tinggi (Santosa, 2018). Berikut merupakan hasil uji koefisien determinasi pada masingmasing tingkat konstruk endogen yang dapat ditampilkan pada Tabel 2 sebagai berikut:

Tabel 2. $R$ square

\begin{tabular}{lc}
\hline \multicolumn{1}{c}{ Konstruk } & R square \\
\hline Kinerja Karyawan & 0.956 \\
Loyalitas Karyawan & 0.810 \\
\hline Sumber : Data Primer (2019), diolah
\end{tabular}

Merujuk pada teori (Santosa, 2018) hasil analisis sesuai pada Tabel 2 menunjukkan bahwa nilai $R$ square konstruk kinerja karyawan sebesar 0.956 . Artinya konstruk kinerja karyawan mampu dijelaskan oleh ketiga konstruk yang diuji dalam model penelitian sebesar

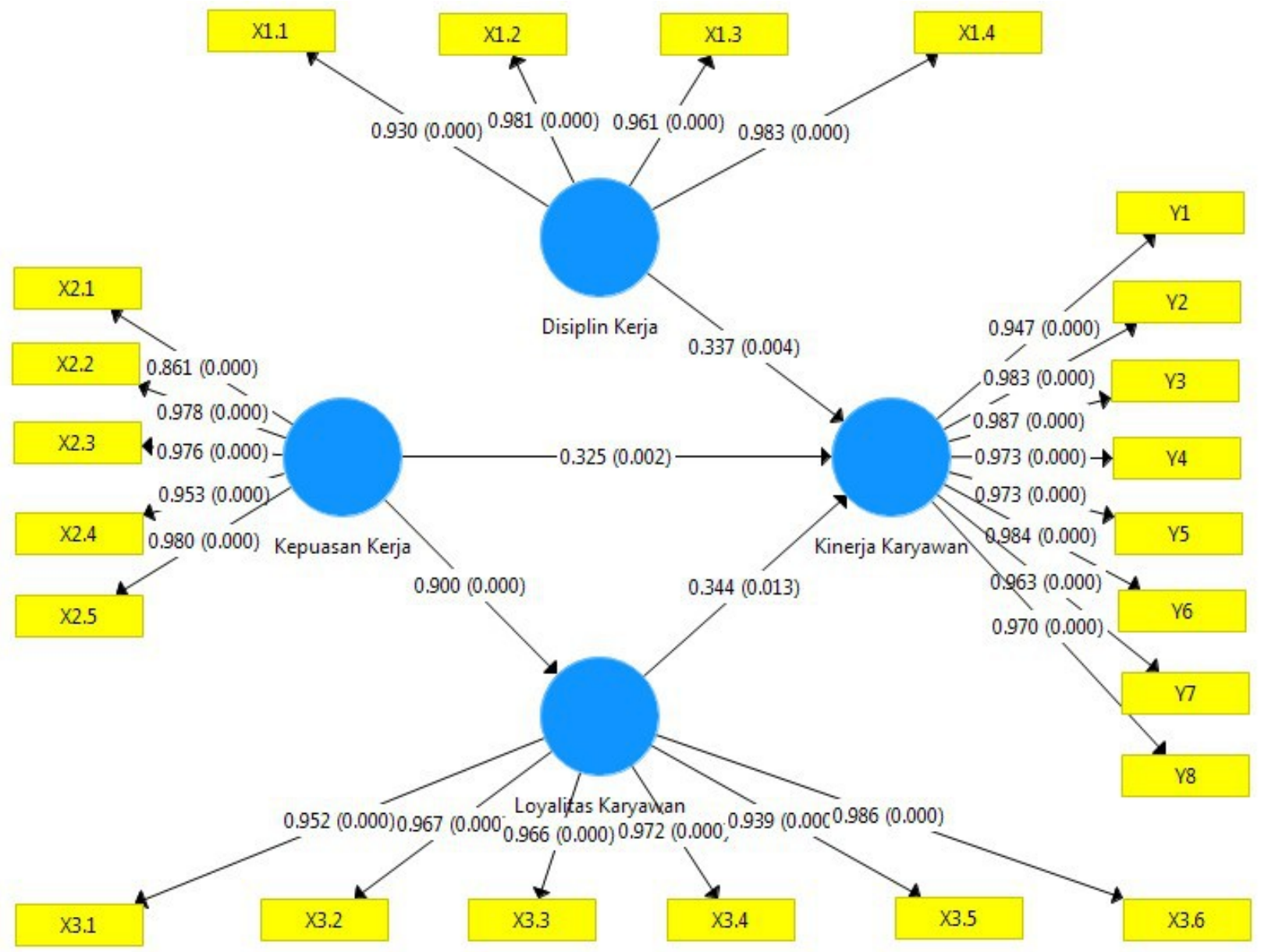

Gambar 1. Output Model Persamaan Struktural berbasis Smart PLS V.3.0 
95,6\% dan 4,4\% dapat dijelaskan oleh konstruk lain yang tidak diteliti dalam penelitian ini. Sedangkan untuk konstruk loyalitas karyawan nilai $R$ square yang diperoleh sebesar 0.810 . Artinya konstruk loyalitas karyawan mampu dijelaskan oleh kepuasan kerja sebesar $81,0 \%$ dan $19 \%$ mampu dijelaskan oleh konstruk lain yang tidak diteliti dalam penelitian ini.

2. Uji GoF (Goodness of Fit)

Pengujian GoF (Goodness of Fit) digunakan untuk mengevaluasi model secara keseluruhan yang dapat dihitung dengan formula sebagai berikut :

$$
G o F=\sqrt{\overline{A V E} * \overline{R \text { square }}}
$$

Persamaan diatas $\overline{A V E}$ merupakan nilai rataan terbobot dengan bobot diperoleh dari jumlah indikator untuk setiap variabel. Menggunakan formula tersebut, maka nilai GoF yang diperoleh sebesar 0.819 , sebuah ukuran yang melebihi nilai ambang $\quad 0.50$ sehingga model bisa diterima dan analisis dapat dilanjutkan.

Mengacu pada hasil analisis, nilai SRMR (Standardized Root Mean Residual) yaitu 0.04 maka model dinyakatakan fit. Hasil tersebut merujuk dari teori (Ghozali, 2012) model persamaan struktural dapat dikatakan fit jika nilai $\mathrm{SRMR}<0,10$ dan model dinyatakan tidak layak jika nilai SRMR > 0.15. Nilai Chi-square diperoleh sebesar 916.313 maka data empiris yang digunakan dalam penelitian ini sangat identik dengan teori yang digunakan, karena Chi-square memiliki rentang nilai $>0.05$. Nilai NFI (Normed Fit Index) diperoleh sebesar $0.710 \quad$ maka mengindikasikan model yang baik, karena rentang nilai NFI $<0.90$. Dari hasil nilai SRMR, Chi-square dan NFI maka model Dalam penelitian ini sudah fit.

\section{Path Coefficient}

Uji Path Coefficients dalam model struktural dilakukan dengan melihat relasi/koefisien jalur konstruk laten yang satu dengan konstruk laten yang lain sesuai dengan hipotesis yang diajukan. Tingkat signifikansi relasi antar konstruk dapat dilihat dari nilai t-hitung (t-statistik) $>$ t-tabel (2.018) dengan taraf signifikansi sebesar 5\% (0,05). Berikut hasil pengujian hipotesis dapat ditunjukkan pada Tabel 3 sebagai berikut :

Tabel 3 menunjukkan secara jelas keempat jalur yang dibangun dalam penelitian ini didukung dengan hasil analisis model struktural. Hasil pengaruh langsung konstruk eksogen terhadap konstruk endogen dengan nilai t-hitung (t-statistik) $>$ t-tabel (2.018) dan taraf signifikan 5\% (0.05) maka Ho ditolak jika nilai $\mathrm{P}$-value $<0.05$, sehingga hasil penelitian secara statistik adalah signifikan dapat dijelaskan sebagai berikut :

1. Disiplin kerja secara langsung mempengaruhi kinerja karyawan dengan nilai nilai T-statistik sebesar 2.931 ( $>2.018)$ dengan taraf signifikan P-value sebesar (0.004) dan diperoleh original sampel positif sebesar 0.337 , maka Ho ditolak dan Ha diterima.

2. Kepuasan kerja secara langsung mempengaruhi kinerja karyawan dengan

Tabel 3. Path Coefficient

\begin{tabular}{lccccc}
\hline \multicolumn{1}{c}{ Konstruk } & $\begin{array}{c}\text { Original } \\
\text { Sampel } \\
(\mathrm{O})\end{array}$ & $\begin{array}{c}\text { Sampel } \\
\text { Mean } \\
(\mathrm{M})\end{array}$ & $\begin{array}{c}\text { Standar } \\
\text { Deviasi }\end{array}$ & T Statistik & P Value \\
\hline disiplin kerja $\rightarrow$ kinerja karyawan & 0.337 & 0.330 & 0.115 & 2.931 & 0.004 \\
kepuasan kerja $\rightarrow$ kinerja karyawan & 0.322 & 0.322 & 0.102 & 3.175 & 0.002 \\
kepuasan kerja $\rightarrow$ loyalitas karyawan & 0.900 & 0.895 & 0.035 & 25.438 & 0.000 \\
loyalitas karyawan $\rightarrow$ kinerja karyawan & 0.344 & 0.354 & 0.131 & 2.628 & 0.009 \\
\hline
\end{tabular}

Sumber : Data primer (2019), diolah 
nilai nilai T-statistik sebesar 3.175 $(>2.018)$ dengan taraf signifikan P-value sebesar (0.002) dan diperoleh original sampel positif sebesar 0.325 , maka Ho ditolak dan Ha diterima.

3. Kepuasan kerja secara langsung mempengaruhi loyalitas karyawan dengan nilai T-statistik sebesar 25.438 $(>2.018)$ dengan taraf signifikan P-value sebesar (0.000) dan diperoleh original sampel positif sebesar 0.900 , maka Ho ditolak dan Ha diterima.

4. Loyalitas karyawan secara langsung mempengaruhi kinerja karyawan dengan nilai nilai T-statistik sebesar 2.628 $(>2.018)$ dengan taraf signifikan P-value sebesar (0.009) dan diperoleh original sampel positif sebesar 0.344 , maka Ho ditolak dan Ha diterima.

\section{Pembahasan}

1. Pengaruh disiplin kerja terhadap kinerja karyawan

Hasil analisis menunjukkan konstruk disiplin kerja didominasi oleh indikator $\mathrm{X} 1.4$ atau "taat peraturan umum perusahaan" dan Indikator X1.1 atau "taat waktu" memiliki nilai paling kecil diantara indikator yang lainnya. permasalahan taat waktu ini berhubungan dengan karakteristik karyawan yang berasal dari daerah yang cukup jauh dari lokasi bekerja, sehingga jam kehadiran karyawan tersebut menjadi kurang tepat waktu. Pengujian hipotesis dapat dijelaskan bahwa antara konstruk disiplin kerja terhadap kinerja karyawan berpengaruh positif dan signifikan secara langsung. Hasil penelitian ini dipertegas kembali dari teori yang dikemukakan oleh Sutrisno (2009) yang menyatakan bahwa melalui disiplin kerja dapat mencerminkan kekuatan, karena seseorang yang berhasil dalam karyanya atau hasil kerja adalah mereka yang memiliki disiplin yang tinggi. Hasil penelitian ini sejalan dengan hasil penelitian yang dilakukan oleh Untari (2018), Tamba (2018) dan Sajangbati (2013) yang menyatakan bahwa disiplin kerja berpengaruh positif dan signifikan terhadap kinerja karyawan.

2. Pengaruh kepuasan kerja terhadap kinerja karyawan

Hasil analisis menunjukkan konstruk kepuasan kerja didominasi oleh indikator X2.5 atau "kepuasan dengan pekerjaan yang dikerjakan" dan Indikator X2.1 atau "kepuasan gaji" memiliki nilai paling kecil diantara indikator penyusun kepuasan kerja dan indikator keseluruhan penyusun model penelitian. Permasalahan kepuasan gaji yang dirasakan oleh karyawan selama bekerja berhubungan dengan karakteristik karyawan yang memiliki tingkat pendidikan yang hanya setara SMA/SLTA, karena sistem pengupahan karyawan pada Agrowisata Bagus Agro Pelaga berdasarkan tingkat pendidikan dan kedudukan para karyawan. disisi lain para karyawan merasa ditekan dan mendapat beban pekerjaan yang banyak sehingga tidak sebanding dengan upah yang diterima. Pengujian hipotesis menunjukkan bahwa konstruk kepuasan kerja berpengaruh positif dan signifikan terhadap kinerja karyawan. Hasil penelitian ini dipertegas kembali oleh teori yang dikemukakan oleh Robbins (1996) menyatakan bahwa organisasi yang karyawannya mendapatkan kepuasan di tempat kerja maka cenderung lebih efektif daripada organisasi yang karyawan kurang mendapatkan kepuasan kerja. Hasil penelitian oleh Indra (2017), Damayanti (2018), Sajangbati (2013) dan Saputra (2016) mengungkapkan pendapat yang sama yaitu kepuasan kerja berpengaruh positif dan signifikan terhadap kinerja karyawan.

3. Pengaruh kepuasan kerja terhadap loyalitas karyawan

Hasil analisis menyatakan kepuasan kerja berpengaruh positif dan signifikan terhadap loyalitas karyawan secara langsung. Hasil penelitian ini dipertegas kembali oleh teori Strauss dan Sayles (1999) menyatakan jika kepuasan tidak 
tercapai, maka dapat terjadi karyawan akan frustasi dan berpengaruh terhadap hasil kerja serta kesetiaan karyawan dengan perusahaan. Hal ini terjadi karena sesuai dengan data yang diperoleh dari lapangan yang menyatakan bahwa kepuasan dengan rekan kerja lebih mendominasi daripada indikator yang lain menyusun kepuasan kerja, sehingga dari hal tersebut dapat membuat rasa loyalitas lebih meningkat. Nilai hubungan anatara kepuasan kerja dengan loyalitas karyawan memiliki nilai paling tinggi dalam model penelitian. Sehingga dapat dijelaskan bahwa kepuasan kerja memang memiliki pengaruh paling tinggi terhadap loyalitas karyawan. Pendapat serupa diperoleh dari hasil penelitian Hadiutama (2008) dan Saputra (2016) yang menyatakan bahwa kepuasan kerja berpengaruh positif dan signifikan terhadap kinerja karyawan.

4. Pengaruh loyalitas karyawan terhadap kinerja karyawan

Hasil analisis menyatakan bahwa loyalitas karyawan didominasi oleh indikator X3.4 atau "rasa memiliki perusahaan" dan Indikator X3.5 atau "hubungan antar pribadi karyawan" memiliki nilai terkecil diantara indikator yang lainnya. permasalahan hubungan pribadi yang terjadi pada beberapa karyawan juga dapat berhubungan dengan karakteristik karyawan perempuan yang lebih mendominasi, sehingga mereka akan lebih mudah terpancing amarah dan terjadi perselisihan. Pengujian hipotesis menunjukkan bahwa konstruk loyalitas karyawan berpengaruh positif dan signifikan terhadap kinerja karyawan. Hasil penelitian ini dipertegas kembali oleh teori Steers dan Porter (1983) bahwa adanya loyalitas karyawan mempunyai pengaruh terhadap kinerja karyawan dan masa kerja. Pendapat yang sama didapatkan dari hasil penelitian Gomes (2017) dan Saputra (2016) yang menyatakan bahwa loyalitas karyawan berpengaruh positif dan signifikan terhadap kinerja karyawan.

\section{SIMPULAN DAN SARAN}

Berdasarkan pada analisis data yang telah dilakukan, maka dapat diambil beberapa kesimpulan dan saran sebagai berikut :

\section{Kesimpulan}

Karakteristik karyawan Agrowisata Bagus Agro Pelaga didominasi oleh masyarakat setempat dengan rata-rata usia masih produktif dan berstatus sudah menikah. Sebagian besar karyawan Agrowisata Bagus Agro Pelaga didomonasi oleh kaum perempuan dan memiliki tingkat pendidikan terakhir pada jenjang SMA/SLTA. Rata-rata lama kerja karyawan pada Agrowisata Bagus Agro Pelaga selama kurang lebih enam tahun. Hasil analisis yang dilakukan menyatakan bahwa dari ketiga konstruk yaitu disiplin kerja, kepuasan kerja dan loyalitas karyawan berpengaruh positif dan signifikan terhadap kinerja karyawan Agrowisata Bagus Agro Pelaga. Loyalitas karyawan memiliki pengaruh yang lebih tinggi terhadap kinerja karyawan dibandingkan disiplin kerja dan kepuasan kerja. Selain itu kepuasan kerja memiliki pengaruh yang positif dan signifikan terhadap loyalitas karyawan.

\section{Saran}

Hasil penelitian menunjukkan bahwa kepuasan kerja karyawan Agrowisata Bagus Agro Pelaga memiliki pengaruh yang lebih kecil terhadap kinerja karyawan. Permasalahan ini disebabkan oleh masingmasing karyawan belum puas dengan gaji yang diterima selama bekerja di Agrowisata Bagus Agro Pelaga, sehingga hal ini perlu diperhatikan oleh pihak manajemen dengan meningkatkan insentif, atau dengan bentuk penghargaan lainnya sehingga dapat meningkatkan kinerja karyawan.

\section{DAFTAR PUSTAKA}

Damayanti, R., A. Hanafi dan A. Cahyadi. 2018. Pengaruh kepuasan kerja terhadap kinerja karyawan (studi kasus karyawan non medis RS Islam Siti Khadijah 
Palembang). Jurnal Ilmiah Manajemen Bisnis \& Terapan. 2(15) : 75-86.

Ghozali, I. 2012. Aplikasi Analisis Multivariate dengan Program IBM SPSS. Semarang. Universitas Diponegoro.

Gomes, L. I. dan E. M. Susanto. 2017. Pengaruh motivasi kerja dan loyalitas karyawan terhadap kinerja karyawan di CV. Hartono Flash Surabaya. AGORA. $5(3): 3-7$.

Hadiutama, J. 2008. Hubungan kepuasan kerja dengan loyalitas karyawan studi kasus pada karyawan Universitas Sanata Dharma Yogyakarta. Program Studi Manajemen. Universitas Sanata Dharma. 2(3) : 37-46.

Indra, G. P., K. K. Heryanda dan N. N. Yulianthini. 2017. Pengaruh kepuasan kerja dan loyalitas laryawan terhadap kinerja karyawan pada Adirama Beach Hotel. Jurnal Jurusan Manajemen. 2(8) : 20-32.

Robbins, S. P. 1996. Perilaku Organisasi, Konsep, Kontroversi-Aplikasi. Jilid 2 Edisi Bahasa Indonesia. Jakarta. Penerbit Prenhalindo.

Sajangbati, I. A. 2013. Motivasi, disiplin, dan kepuasan pengaruhnya terhadap kinerja pegawai PT. Pos Indonesia (persero) cabang Bitung. EMBA. 1(4) : 673-677.

Santosa, P. I. 2018. Metode Penelitian Kuantitatif-Pengembangan Hipotesis dan Pengujiannya Menggunakan SmartPLS. Yogyakarta. CV. Andi Offset.
Saputra, A. T., I. W. Bagia dan N. N. Yulianthini. 2016. Pengaruh kepuasan kerja dan loyalitas karyawan terhadap kinerja karyawan PT. Sun Star Motor Cabang Negara. Jurnal Jurusan Manajemen. 4(1) : 4-6.

Steers, R. M and Porter, R. W. 1983. Motivation and Work Behavior. New York. Mc Graw Hill.

Strauss, G. dan L. Sayles. 1999. Manajemen Personalia (Terjemahan Early Sundari). Jakarta. Salemba Empat.

Suryawardani, I G. A. O. 2018. Evaluation of marketing strategy of Sanur Village festival based on visitor's behavior. 16(2): 261-276.

Susanto, N. 2019. Pengaruh motivasi kerja, kepuasan kerja dan disiplin kerja terhadap kinerja karyawan pada divisi penjualan PT. Rembaka. AGORA. 1(7) : $1-6$.

Sutrisno, H. E. 2009. Manajemen Sumber Daya Manusia. Jakarta. Prenadamedia Group.

Tamba, A. W., R. J. Pio dan S. A. P. Sambul. 2018. Pengaruh disiplin kerja dan loyalitas karyawan terhadap kinerja karyawan pada PT. Columbindo Perdana Cabang Manado. Jurnal Administrasi Bisnis. 1(7) : 33-41.

Untari, D. 2018. Pengaruh disiplin kerja terhadap kinerja pegawai pada PT. Kie Indonesia. JIFE. 1(7) : 1-15. 